\title{
TINJAUAN PUSTAKA SISTEMATIS PADA BASIS DATA PUSTAKA DIGITAL: TREN RISET, METODOLOGI, DAN COVERAGE FIELDS
}

\author{
Aris Yaman ${ }^{1 *}$, Ambar Yoganingrum ${ }^{2}$, Yaniasih $^{3}$, Slamet Riyanto $^{4}$ \\ 1,2,3,4 Pusat Penelitian Informatika, Lembaga Ilmu Pengetahuan Indonesia \\ *Korespondensi: aris.yaman@gmail.com
}

Diajukan: 08-02-2019; Direview: 20-02-2019; Diterima: 30-02-2019; Direvisi: 14-05-2019

\begin{abstract}
The characterization of digital databases is needed to make it easier for academics to identify scientific literature properly and efficiently. This literature review intends to provide characterizations and descriptions related to research trends, methods and coverage fields studied in research related to the scientific database of scientific literature from around 2007 to the present (January 2019). By applying the specified inclusion and exclusion criteria, 54 relevant studies were chosen to be studied further. The systematic literature review method was applied in this study to analyze and identify previous studies related to this topic. Based on the selected primary literature there is an increasing trend of studies related to the scientific database of scientific literature. In addition, we can see that there are four of the most influential and influential publication journals related to this topic, namely the Journal of Informetrics, Journal of Cleaner Production, Asian Social Science and Journal of Academic Librarianship which are characterized by high levels of productivity issues related to the topics studied and SJR values rank is in the range Q1. Most of the studies were conducted on Scopus digital database (41\%), Web of Sciences (WoS) 38\% and Google Scholar (GS) 13\% and the rest spread in other publication journals. The results of this study also identified that Scopus is a scientific database which has the most varied coverage fields compared to other digital database scientific literature. WoS is a digital database of scientific literature that has proven to have a paper with a higher impact factor than others. GS has the predicate digital database with the largest collection level.
\end{abstract}

\begin{abstract}
ABSTRAK
Karakterisasi basis data digital perlu dilakukan, supaya dapat mempermudah para akademia melakukan identifikasi terhadap literatur ilmiah dengan tepat dan efisien. Tinjauan literatur ini bermaksud memberikan karakterisasi dan gambaran terkait tren riset, metode, dan coverage fields yang dikaji dalam penelitian terkait basis data digital literatur ilmiah pada kisaran tahu 2007 hingga saat ini (Januari 2019). Kriteria inklusi dan ekslusi yang telah ditetapkan, terpilih sebanyak 54 kajian yang relevan untuk dipelajari lebih lanjut. Metode tinjauan pustaka sistematis diterapkan dalam kajian ini untuk menganalisis dan mengidentifikasi kajian-kajian terdahulu terkait topik ini. Berdasarkan literatur primer yang dipilih diketahui terjadi tren peningkatan kajian terkait basis data digital literatur ilmiah. Selain itu, teridentifikasi terdapat empat jurnal publikasi paling berdampak dan berpengaruh terkait topik ini, yaitu Journal of Informetrics, Journal of Cleaner Production, Asian Social Science dan Journal of Academic Librarianship yang ditandai dengan tingkat produktivitas terbitan terkait topik yang diteliti termasuk tinggi dan nilai SJR rank berada pada kisaran Q1. Sebagian besar kajian dilakukan pada basis data digital Scopus (41\%), Web of Sciences (WoS) 38\% dan Google Scholar (GS) sebesar 13\% serta sisanya menyebar di jurnal publikasi lainnya. Hasil kajian ini juga mengidentifikasi bahwa Scopus merupakan basis data ilmiah yang memliki tingkat coverage fields yang paling beragam dibanding basis data digital literatur ilmiah lainnya. WoS merupakan basis data digital literatur ilmiah yang terbukti memiliki paper dengan impact factor lebih tinggi dibanding yang lainnya. GS memiliki predikat basis data digital dengan tingkat koleksi paling besar.
\end{abstract}

Keywords: Database; Scientific publication; Digital; Coverage fileds; Systematic literature review 


\section{PENDAHULUAN}

Ranking publikasi ilmiah Indonesia berada di peringkat 52 dari 239 negara yang terdaftar. Posisi ini jauh di bawah Singapura dan Malaysia yang saat ini berada diperingkat 32 dan 34 (Scimago Lab, 2019) yang tergabung dalam kawasan ASEAN. Hal ini mengindikasikan bahwa tingkat produktivitas publikasi ilmiah Indonesia masih rendah di tingkat internasional. Salah satu penyebab rendahnya jumlah publikasi ilmiah Indonesia di tingkat internasional karena tingkat kebaruan yang rendah (Nanang, 2015). Masalah kebaruan dan produktivitas ini sebagai akibat dari rendahnya akses pada referensi primer dan kekurang-mutakhiran pustaka acuan khususnya e-journal yang digunakan oleh peneliti dan akademisi di Indonesia (Vakkari, 2008). Hal tersebut dapat diatasi apabila para peneliti dan akademisi difasilitasi untuk dapat mengakses dan mengarahkan pada basis data (database) literatur ilmiah yang memiliki reputasi yang baik.

Selain memiliki reputasi dan kualitas literatur ilmiah yang baik, akademisi juga diharapkan dapat memberdayakan literatur yang tepat sesuai denga kepakaran dan penelitian yang dilakukan. Justifikasi satu database literatur ilmiah lebih baik dibandingkan literatur ilmiah lainnya tidak dapat disimpulkan secara general, hal ini lebih bergantung pada subjek tertentu. Beberapa peneliti mengusulkan melakukan analisis khusus subjek untuk mengetahui basis data mana yang paling cocok untuk bidang atau periode waktu tertentu (Chou, 2012).

Saat ini di dunia terdapat beberapa basis data digital literatur ilmiah yang memiliki reputasi yang baik (diindikasikan oleh banyaknya artikel ilmiah yang dimuat memliki h-indeks dan sitasi yang tinggi) diantaranya Web of Science (WoS), Scopus, Ebsco, Proquest, dan Science Direct. Kelima basis data saat ini dilanggan oleh Kementerian Riset, Teknologi, dan Pendidikan Tinggi (Kemenristek-Dikti) guna meningkatkan kapasitas dan produktivitas ilmiah para akademisi. Karakterisasi basis data digital ini perlu dilakukan untuk mempermudah para akademisi melakukan identifikasi terhadap literatur ilmiah dengan tepat dan efisien. Kajian ini bertujuan untuk memberikan karakterisasi dan gambaran terkait tren riset, metode, dan coverage fields pada jurnal ilmiah terlanggan.

\section{TINJAUAN PUSTAKA}

Database WoS merupakan produk dari Institute of Scientific Information (ISI) Thomson Reuters, berawal dari aplikasi SCI/science citation Index di tahun 1960-an oleh Eugene Garfield. WoS mencakup lebih dari 10.000 jurnal dan terdiri dari tujuh basis data sitasi termasuk berbagai informasi yang dikumpulkan dari jurnal, konferensi, laporan, buku, dan buku berseri. WoS merupakan basis data lieratur ilmiah tertua yang memiliki cover area yang beragam dengan data sitasi dan data bibliografi (Boyle \& Sherman, 2006).

Scopus merupakan produk dari Elsevier Science, Scopus dibuat untuk menjadi pesaing WoS baik dalam hal pengindeks artikel ilmiah maupun basis data literatur ilmiah. Scopus dilaunching pada bulan November 2004. Scopus mengklaim memiliki basis data yang sangat besar dengan jangkaun record yang luas. Scopus memiliki fitur untuk melakukan analisis, tracking, dan visualisasi terkait artikel yang di cari (Boyle \& Sherman, 2006). ScienceDirect dan Scopus adalah basis data literatur ilmiah akses langganan yang dimiliki oleh penerbit Elsevier. ScienceDirect menampung teks lengkap dari konten Elsevier sedangkan Scopus menyertakan abstrak dan statistik kutipan tentang konten Elsevier dan non-Elsevier.

Perbandingan antara WoS dan Scopus diketahui bahwa Scopus memiliki jumlah jurnal yang lebih banyak dibanding WoS, namun impact factor-nya yang lebih rendah. Perbandingan kedua basis data literatur ilmiah ini dijelaskan pada Gambar 1. 


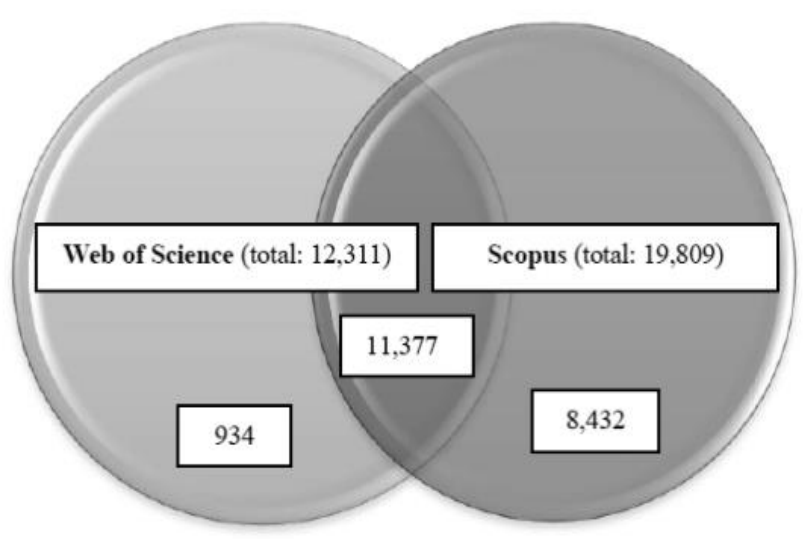

Gambar 1. Perbandingan cakupan antara WoS dan Scopus (Chadegani et al, 2017)

WoS dan Scopus memiliki kesamaan dalam hal kemampuan pencarian dan pengurutan parameter yang diinginkan pengguna (Chadegani, et al, 2017). Akademik literatur WoS dan Scopus terbukti siginifikan dapat meningkatkan peringkat relatif para penggunanya khususnya para akademisi (Meho \& Yang, 2007).

Ebsco menyediakan sumber informasi bagi para akademisi terkait artikel ilmiah. Ebsco merupakan salah satu jenis database aggregator, di mana hanya melisensi konten-konten dari berbagai penerbit dan tidak menerbitkan jurnal sendiri. Kelebihan agregator adalah konten yang mereka miliki lebih banyak dan bervariasi karena memiliki akses untuk melisensi dari banyak penerbit. Sedangkan suatu penerbit, hanya menghadirkan artikel yang mereka terbitkan sendiri sehingga jumlah dan topiknya lebih terbatas. Kelemahan yang ada pada database aggregator adalah dapat terkena embargo dari penerbit utama sehingga artikel atau jurnal yang diakses tidak dapat dilihat secara full text (Maryatun, 2016).

Proquest juga merupakan database aggregator. Ribuan jurnal dari berbagai bidang kajian terdapat dalam Proquest online. Format dalam bentuk teks grafis, page image (.pdf) dan abstraksi disediakan dalam Proquest. Ebsco diklaim memiliki jumlah artikel ilmiah yang lebih banyak dibanding Proquest, dengan tingkat duplikasi artikel pada masing-masing database aggregator sebesar 24,88\% dan 27,81\% (Maryatun, 2016). Proquest juga memiliki keunggulan konten dalam bidang kajian ekonomi dan manajemen (Karyatin, 2013).

Federated Search merupakan fasilitas layanan satu pintu yang disediakan KemenristekDikti untuk mengakses seluruh artikel ilmiah dari berbagai e-resources terlanggan. Kajian terkait perbandingan antar pustaka ilmiah digital telah banyak dilakukan oleh peneliti terdahulu. Akan tetapi, penelitian terdahulu paling banyak membandingkan sebanyak tiga buah pustaka ilmiah digital (Ellegaard \& Wallin, 2013; Karyatin, 2013; Levine-Clark \& Gil, 2009).

Tinjauan pustaka sistematis (Systematic Literature Review/SLR) merupakan metode ulasan yang saat ini banyak digunakan para peneliti maupun akademisi dalam mengulas literatur ilmiah. Hal ini disebabkan karena metode SLR dapat menghindari terjadinya bias dan pemahaman yang subjektif dari penelitiannya (Kitchenham \& Charters, 2007). SLR sudah terbukti menjadi metode yang secara efeketif dapa memberikan gambaran mengenai tren riset, metodologi, dan coverage field riset pada penelitian sebelumnya (Borrett et al, 2018; Wahono, 2015; Ha, Park, \& Kim, 2014). 


\section{METODE}

\subsection{Metode Ulasan}

Pendekatan sistematis digunakan untuk meninjau literatur ilmiah terkait tinjauan/perbandingan antar basis data literatur ilmiah. Kajian ini mengadopsi prosedur yang dilakukan oleh Wahono (2015) yang mengkaji tentang Software Defect Prediction (Gambar 2). Pada dasarnya SLR terbagi menjadi tiga tahapan, yaitu: perencanaan, pelaksanaan, dan pelaporan.

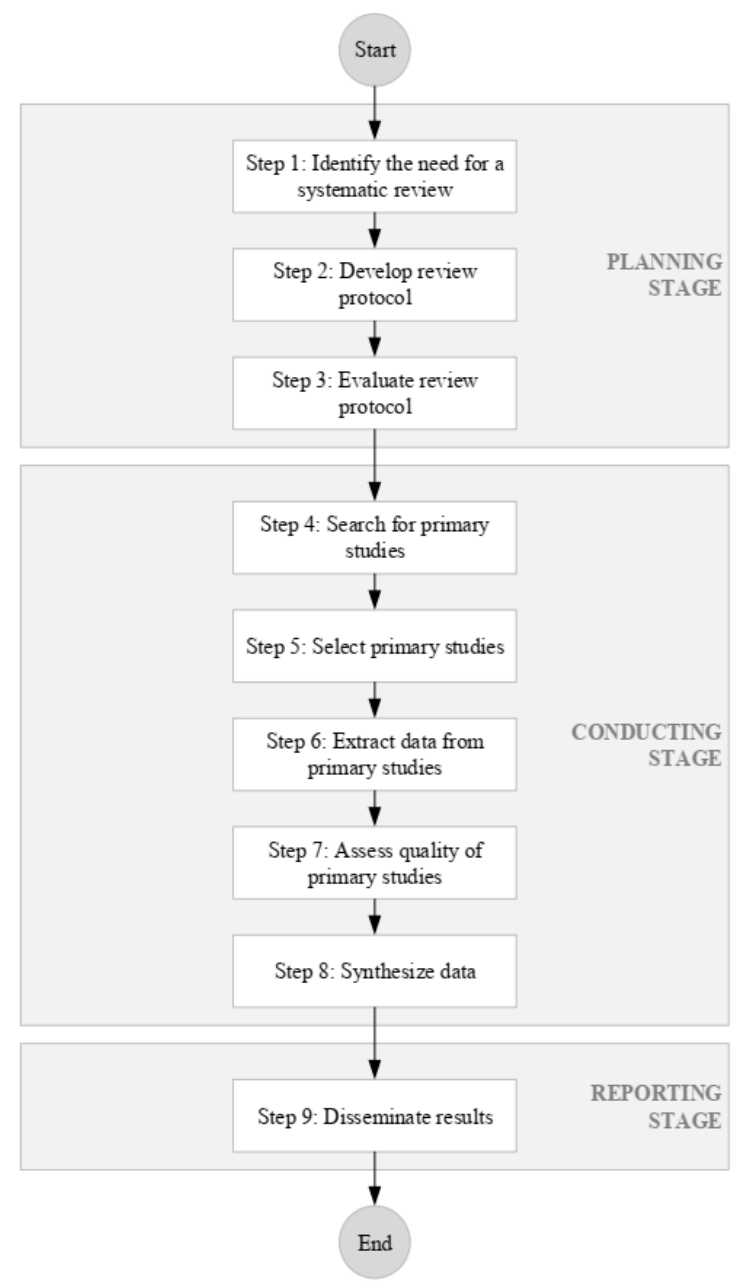

Gambar 2. Tahapan SLR (Kitchenham \& Charters, 2007)

\subsection{Pertanyaan Penelitian}

Pertanyaan Penelitian (Research Question/RQ) adalah identifikasi awal dan dasar pada metode SLR. RQ bertujuan untuk membuat proses pencarian dan ekstrasksi literatur sistematis dan terarah. Pendekatan PICOC digunakan untuk merancang RQ yang baik (Kitchenham \& Charters, 2007). Tabel 1 menunjukkan struktur PICOC pada RQ.

Tabel 1. Rangkuman PICOC kajian

\begin{tabular}{|l|l|}
\hline Population & Basis data literatur ilmiah, Academic Literature, WoS, Scopus \\
\hline Intervention & $\begin{array}{l}\text { Karakteristik tiap basis data ilmiah, keunggulan basis data literatur, kelemahan } \\
\text { basis data literatur, basis data paling unggul }\end{array}$ \\
\hline Comparison & - \\
\hline
\end{tabular}




\begin{tabular}{|l|l|}
\hline Outcomes & Cakupan bidang spesifik untuk tiap basis data literatur ilmiah terlanggan \\
\hline Context & Studi terkait basis data terlanggan oleh Kemenristek-Dikti \\
\hline
\end{tabular}

Pertanyaan penelitian dan tujuan pertanyaan yang dibahas dalam tinjauan pustaka kajian ini ditunjukkan pada Tabel 2.

Tabel 2. Pertanyaan Penelitian pada Tinjauan Pustaka

\begin{tabular}{|c|l|l|}
\hline Id & \multicolumn{1}{|c|}{ Pertanyaan Penelitian } & \multicolumn{1}{c|}{ Tujuan } \\
\hline PR1 & $\begin{array}{l}\text { Jurnal mana yang merupakan jurnal } \\
\text { tinjauan basis data literatur ilmiah } \\
\text { paling signifikan? }\end{array}$ & $\begin{array}{l}\text { Untuk memprediksi jurnal mana yang paling } \\
\text { berpengaruh dalam hal kajian terkait basis data } \\
\text { literature ilmiah }\end{array}$ \\
\hline PR2 & $\begin{array}{l}\text { Siapa peneliti paling aktif dan } \\
\text { berpengaruh dalam mengkaji basis } \\
\text { data literatur ilmiah? }\end{array}$ & $\begin{array}{l}\text { Identifikasi peneliti yang paling aktif dan } \\
\text { berpengaruh yang berkontribusi banyak } \\
\text { mengkaji basis data literatur ilmiah }\end{array}$ \\
\hline PR3 & $\begin{array}{l}\text { Basis data apa yang sering digunakan } \\
\text { dalam mengkaji basis data literatur } \\
\text { ilmiah? }\end{array}$ & $\begin{array}{l}\text { Identifikasi basis data yang paling sering } \\
\text { digunakan dalam kajian literatur ilmiah }\end{array}$ \\
\hline PR4 & $\begin{array}{l}\text { Basis data apa yang paling baik } \\
\text { digunakan dalam mengkaji basis data } \\
\text { literatur ilmiah? }\end{array}$ & $\begin{array}{l}\text { Identifikasi basis data terbaik dalam mengkaji } \\
\text { basis data lietratur ilmiah }\end{array}$ \\
\hline PR5 & $\begin{array}{l}\text { Basis data mana yang dapat } \\
\text { menampilkan pencarian terbaik } \\
\text { dalam tinjauan literatur? }\end{array}$ & $\begin{array}{l}\text { Mengidentifikasi basis data yang berkinerja } \\
\text { terbaik }\end{array}$ \\
\hline PR6 & $\begin{array}{l}\text { Metode identifikasi seperti apa yang } \\
\text { diusulkan untuk mencari basis data } \\
\text { terbaik literatur ilmiah }\end{array}$ & $\begin{array}{l}\text { Mengidentifikasi metode penentuan untuk } \\
\text { menilai basis data yang berkinerja terbaik }\end{array}$ \\
\hline PR7 & $\begin{array}{l}\text { Coverage fields seperti apa yang } \\
\text { diusulkan untuk karakterisasi basis } \\
\text { data literatur ilmiah? }\end{array}$ & $\begin{array}{l}\text { Identifikasi bidang untuk karakterisasi basis data } \\
\text { literatur ilmiah }\end{array}$ \\
\hline
\end{tabular}

PR4 sampai PR7 merupakan pikiran utama RQ, sementara PR1-PR3 untuk mengevaluasi konteks dari kajian utama. PR1-PR3 memberikan informasi simpulan dan sinopsis beberapa bidang riset pada bidang kajian terkait basis data literatur ilmiah.

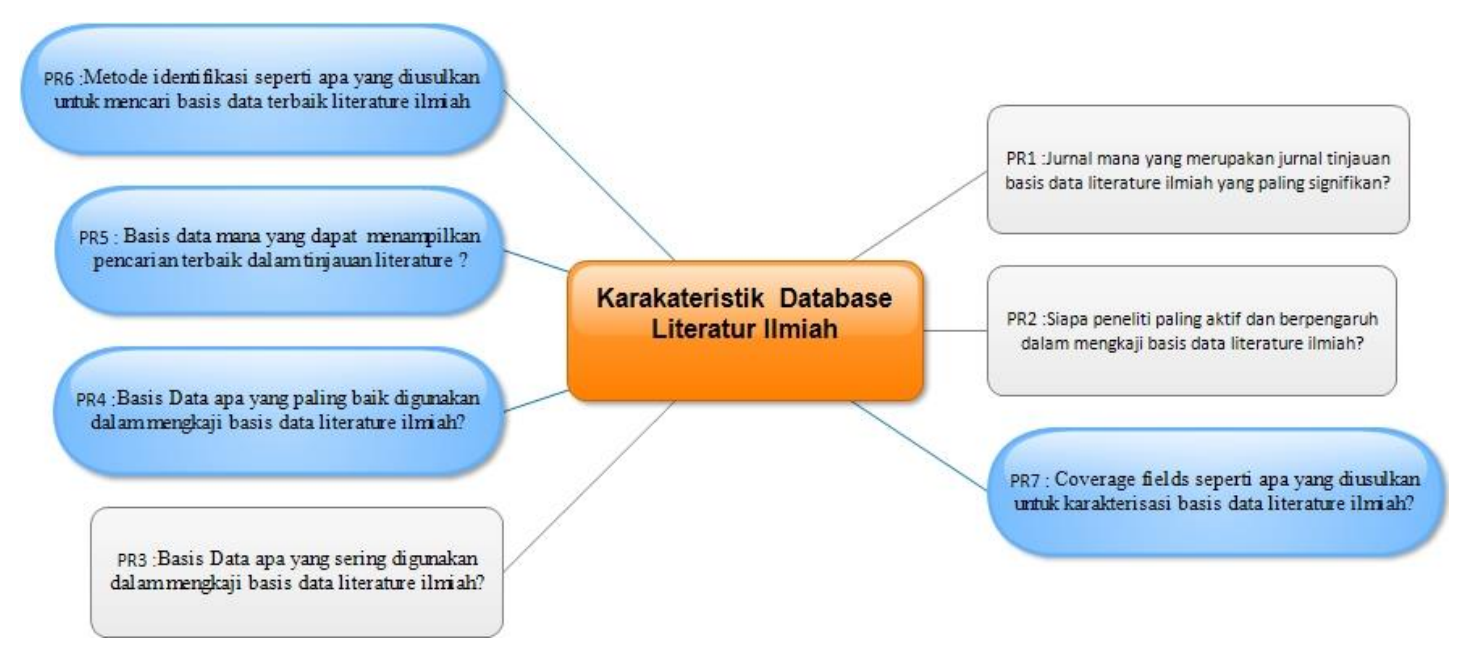

Gambar 3. Basic mind map mengenai karakterisasi basis data literatur ilmiah

Gambar 3 menunjukkan basic mind map dari SLR. Tujuan utama SLR kajian ini adalah untuk mengidentifikasi basis data literatur ilmiah terbaik, cakupan bidang dan metode penentuannya. 


\subsection{Strategi Pencarian}

Proses pencarian tinjauan pustaka terdiri dari beberapa kegiatan, seperti memilih digital library, menentukan kata kunci, mengeksekusi kata kunci, mengkoreksi kata kunci, dan mengambil daftar awal sumber literatur dari digital library yang cocok dengan kata kunci pencarian. Sebelum memulai pencarian, satu set database yang sesuai harus dipilih untuk meningkatkan kemungkinan menemukan artikel yang sangat relevan. Basis data literatur yang paling populer di lapangan dicari untuk memiliki data set literatur seluas mungkin. Perspektif yang luas diperlukan untuk cakupan literatur yang luas dan luas. Basis data digital literatur ilmiah yang digunakan dalam kajian ini adalah Science Direct (sciencedirect.com) dan Scopus (scopus.com).

Penentuan kata kunci pencarian menggunakan langkah-langkah sebagai berikut (Wahono 2015):

1) mengidentifikasi kata kunci melalui PICOC, terutama bagian population dan intervention;

2) mengidentifikasi melalui RQ yang telah dibuat;

3) mengidentifikasi kata kunci melalui tampilan abstrak, keyword, dan judul yang relevan;

4) mengidentifikasi sinonim, antonim, dan alternatif kata dari kata kunci pencarian;

5) mengkonstruksi string pencairan lanjut dengan menggunakan Boolean AND dan OR.

Berikut merupakan kata kunci pencairan yang dibuat:

(compara* OR Differ*) AND ("Academic Literature" OR "Digital Library" OR (WoS AND Scopus) AND (method*)

Basis data dicari berdasarkan judul, keyword, content, dan abstrak. Publikasi dengan kategori jurnal dan konferensi dimasukan ke dalam kriteria. Artikel yang masuk hanya dalam bahasa Inggris.

\subsection{Penyeleksian Kajian}

Kriteria seleksi inklusi dan eksklusi yang digunakan untuk mendapatkan literatur utama yang dikaji (Tabel 3).

Tabel 3. Kriteria Inklusi dan Eksklusi

\begin{tabular}{|l|l|}
\hline \multirow{4}{*}{ Kriteria Inklusi } & Kajian terkait basis data digital literatur ilmiah \\
\cline { 2 - 2 } & Kajian terkait perbandingan antar basis data digital literatur ilmiah \\
\cline { 2 - 2 } & Kajian terkait cakupan bidang terbaik pada basis data digital library \\
\cline { 2 - 2 } & $\begin{array}{l}\text { Untuk kajian yang sama yang terdapat baik pada jurnal maupun } \\
\text { konferensi maka dipilih jurnal }\end{array}$ \\
\cline { 2 - 2 } & $\begin{array}{l}\text { Untuk kejadian duplikasi kajian yang dipilih adalah yang paling lengkap } \\
\text { dan terbaru }\end{array}$ \\
\hline Kriteria Eksklusi & Kajian tanpa validasi \\
\cline { 2 - 2 } & Literatur tanpa menyertakan full text \\
\cline { 2 - 2 } & Literatur bukan dalam bahasa Inggris \\
\hline
\end{tabular}




\section{HASIL DAN PEMBAHASAN}

\subsection{Publikasi Jurnal Berpengaruh}

Ada 54 kajian utama yang dianalisis performanya terkait basis data digital literatur ilmiah. Distribusi publikasi terkait hal ini setiap tahun akan ditampilkan untuk memperlihatkan tren pengembangan. Gambar 4 menunjukkan tren perkembangan kajian terkait basis data digital. Diketahui bahwa tren peningkatan kajian terkait basis data digital library dimulai pada tahun 2012.

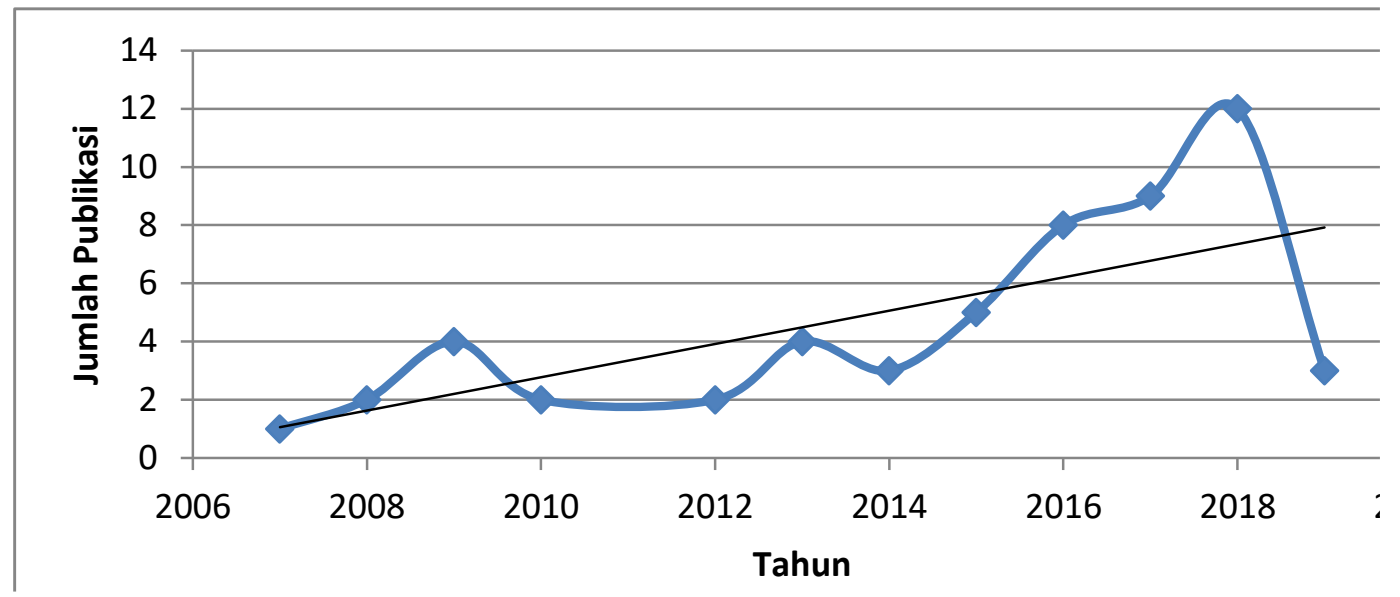

Gambar 4. Distribusi perkembangan jumlah publikasi

Berdasarkan Gambar 4 diketahui bahwa kajian terkait basis data digital library masih menarik, hal ini terlihat dari tren yang cenderung meningkat dari tahun ke tahun. Berdasarkan literatur terpilih, jurnal publikasi yang paling banyak mengeluarkan kajian terkait basis data digital library adalah Journal of Informetrics, diikuti Journal of Cleaner Production, Asian Social Science, dan Journal of Academic Librarianship (Gambar 5).

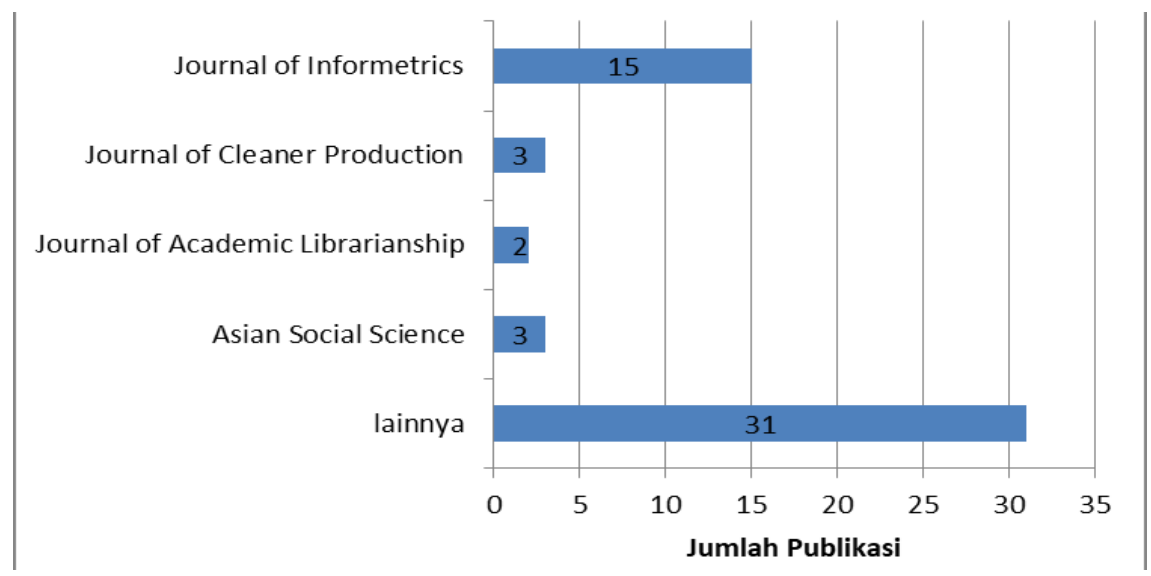

Gambar 5. Publikasi jurnal dan distribusi dari literature terpilih

Tabel 4 memperlihatkan kualitas jurnal hasil identifikasi pada Gambar 5. Terlihat bahwa Journal of Informetrics, dari sisi jumlah ataupun kualitas merupakan jurnal terbaik dalam hal basis data pustaka digital. 
Tabel 4. Scimago Journal Rank (SJR) dari Literatur Terpilih

\begin{tabular}{|c|l|c|l|}
\hline No. & \multicolumn{1}{|c|}{ Nama Jurnal } & SJR & \multicolumn{1}{|c|}{ Kategori Q } \\
\hline 1 & Journal of Informetrics & 2.01 & Q1 in Applied Mathematics \\
\hline 2 & Journal of Cleaner Production & 1.47 & Q1 in Environmental Science \\
\hline 3 & Asian Social Science & 0.14 & Q3 in Art and Humanities \\
\hline 4 & Journal of Academic Librarianship & 1.22 & Q1 in Education \\
\hline
\end{tabular}

\subsection{Peneliti Teraktif dan Berpengaruh}

Dari literatur primer yang dipilih, peneliti yang berkontribusi sangat baik dan aktif dalam bidang tinjauan basis data ilmiah digital. Gambar 6 menunjukkan peneliti yang paling aktif dan berpengaruh di kajian ini. Para peneliti terdaftar sesuai dengan jumlah publikasi yang termasuk dalam literatur primer, di antaranya Chadegani, Arezoo Aghaei (peneliti paling aktif dalam kajian terkait basis data digital).

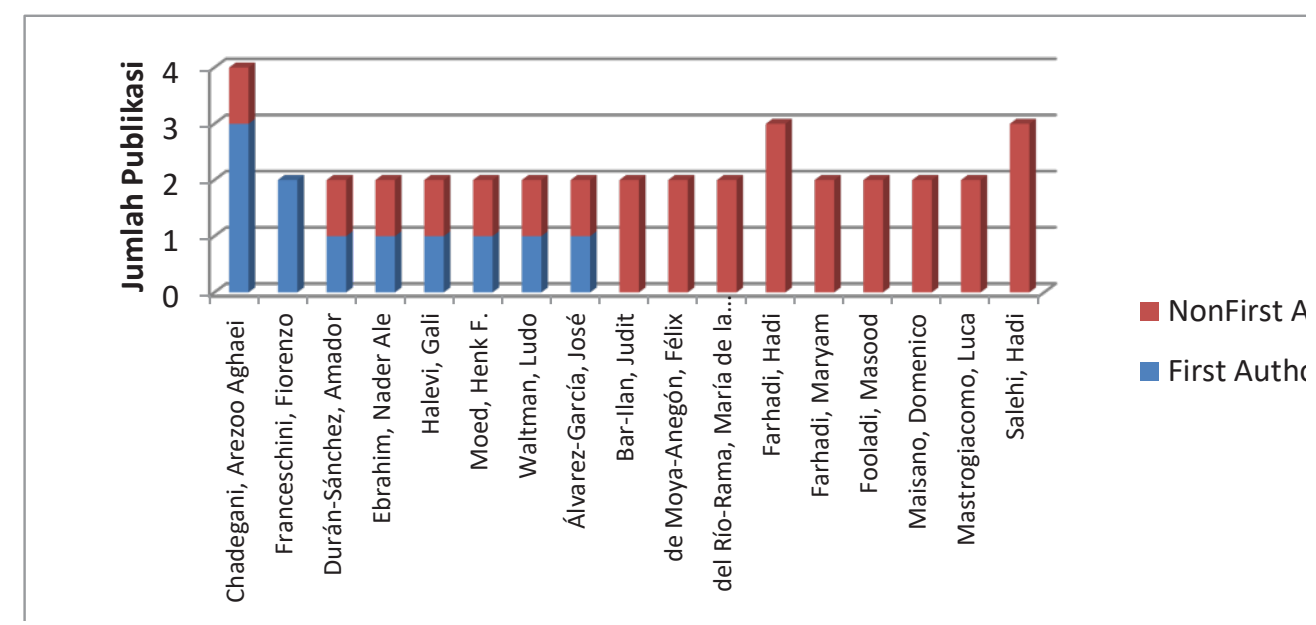

Gambar 6. Peneliti berpengaruh dan jumlah publikasi

\subsection{Karakteristik dan Perbandingan Database}

Kajian terkait karakteristik dan perbandingan database berdasarkan coverage subject dan methodology ditampilkan pada Tabel 5.

Tabel 5. Daftar Literatur Primer Kajian dan Perbandingan Basis Data

\begin{tabular}{|c|c|c|c|c|c|c|c|}
\hline Tahun & Referensi & Judul & Jurnal & Covered Area & Method & Database & Hasil \\
\hline 2007 & (Meho \& Yang, 2007) & $\begin{array}{l}\text { Impact of Data Sources on } \\
\text { Citation Counts and } \\
\text { Rangkings of LIS Faculty: } \\
\text { Web of Science Versus } \\
\text { Scopus and Google Scholar }\end{array}$ & $\begin{array}{l}\text { Online } \\
\text { Information } \\
\text { Review }\end{array}$ & General & $\begin{array}{l}\text { Citation } \\
\text { Counts and } \\
\text { Rankings }\end{array}$ & $\begin{array}{l}\text { WoS, Google } \\
\text { Scholar (GS) }\end{array}$ & $\begin{array}{l}\text { Collecting and } \\
\text { processing time, } \\
\text { WoS }<\text { Scopus } \\
<\text { GS }\end{array}$ \\
\hline \multirow[t]{2}{*}{2008} & $\begin{array}{l}\text { (López-Illescas, de } \\
\text { Moya-Anegón,\& Moed, } \\
\text { 2008) }\end{array}$ & $\begin{array}{l}\text { Coverage and citation } \\
\text { impact of oncological } \\
\text { journals in the Web of } \\
\text { Science and Scopus }\end{array}$ & $\begin{array}{l}\text { Journal of } \\
\text { Informetrics }\end{array}$ & $\begin{array}{l}\text { Medical } \\
\text { Oncology }\end{array}$ & $\begin{array}{l}\text { Coverage and } \\
\text { Citation } \\
\text { Impact }\end{array}$ & WoS, Scopus & $\begin{array}{l}\text { Coverage } \\
\text { (Scopus }> \\
\text { Wos), Impact } \\
\text { factor (Scopus }< \\
\text { WoS) }\end{array}$ \\
\hline & (Gavel and Iselid, 2008) & $\begin{array}{l}\text { Web of Science and Scopus: } \\
\text { A journal title overlap study }\end{array}$ & $\begin{array}{l}\text { Procedia } \\
\text { Computer } \\
\text { Science }\end{array}$ & General & $\begin{array}{l}\text { Overlap } \\
\text { Study }\end{array}$ & WoS, Scopus & \\
\hline 2009 & $\begin{array}{l}\text { (Casagrandi \& Guariso, } \\
\text { 2009) }\end{array}$ & $\begin{array}{l}\text { Impact of ICT in } \\
\text { Environmental Sciences: A } \\
\text { citation analysis 1990-2007 }\end{array}$ & $\begin{array}{l}\text { European } \\
\text { Journal of } \\
\text { Operational } \\
\text { Research }\end{array}$ & ICT & Trend & WoS & \\
\hline
\end{tabular}


Tinjauan Pustaka Sistematis Pada Basis Data Pustaka Digital ... I Aris Yaman, dkk

\begin{tabular}{|c|c|c|c|c|c|c|c|}
\hline & $\begin{array}{l}\text { (Guz \& Rushchitsky, } \\
\text { 2009) }\end{array}$ & $\begin{array}{l}\text { SCOPUS : A System For The } \\
\text { Evaluation Of Scientific } \\
\text { Journals }\end{array}$ & $\begin{array}{l}\text { International } \\
\text { Journal of } \\
\text { Project } \\
\text { Management }\end{array}$ & $\begin{array}{l}\text { Applied } \\
\text { Mechanics }\end{array}$ & $\begin{array}{l}\text { Content } \\
\text { analysis }\end{array}$ & Scopus & \\
\hline & $\begin{array}{l}\text { (Levine-Clark \& Gil, } \\
\text { 2009) }\end{array}$ & $\begin{array}{l}\text { A comparative citation } \\
\text { analysis of web of science, } \\
\text { scopus, and google scholar. }\end{array}$ & $\begin{array}{l}\text { Journal of } \\
\text { Cleaner } \\
\text { Production }\end{array}$ & $\begin{array}{l}\text { Bisnis, } \\
\text { ekonomi }\end{array}$ & Impact factor & $\begin{array}{l}\text { WoS, Scopus, } \\
\text { GS }\end{array}$ & $\begin{array}{l}\text { GS can be } \\
\text { alternative }\end{array}$ \\
\hline & (Bornmann et al., 2009) & $\begin{array}{l}\text { Convergent validity of } \\
\text { bibliometric Google Scholar } \\
\text { data in the field of chemistry- } \\
\text { Citation counts for papers } \\
\text { that were accepted by } \\
\text { Angewandte Chemie } \\
\text { International Edition or } \\
\text { rejected but published } \\
\text { elsewhere, using Google } \\
\text { Scholar, Science Citation } \\
\text { Index, Scopus, and Chemical } \\
\text { Abstracts }\end{array}$ & $\begin{array}{l}\text { Journal of } \\
\text { Informetrics }\end{array}$ & Chemistry & Citation count & GS, Scopus & $\begin{array}{l}\text { GS sama } \\
\text { dengan data } \\
\text { base berbayar }\end{array}$ \\
\hline \multirow[t]{2}{*}{2010} & $\begin{array}{l}\text { (Hwang, Wei, \& Liao, } \\
\text { 2010) }\end{array}$ & $\begin{array}{l}\text { Coauthorship Networks and } \\
\text { Academic Literature } \\
\text { Recommendation }\end{array}$ & $\begin{array}{l}\text { Ilmu } \\
\text { Perpustkaan } \\
\text { dan Informasi }\end{array}$ & & & & \\
\hline & $\begin{array}{l}\text { (Moussa \& Touzani, } \\
\text { 2010) }\end{array}$ & $\begin{array}{l}\text { Ranking marketing journals } \\
\text { using the Google Scholar- } \\
\text { based hg-index }\end{array}$ & $\begin{array}{l}\text { Journal of } \\
\text { The } \\
\text { American } \\
\text { Society for } \\
\text { Information } \\
\text { Science and } \\
\text { Technology }\end{array}$ & Marketing & $\begin{array}{l}\text { Hirsch-type } \\
\text { index }\end{array}$ & GS & $\begin{array}{l}\text { hg- } \\
\text { rankingberimpli } \\
\text { kasi pada } \\
\text { impact factor }\end{array}$ \\
\hline \multirow[t]{2}{*}{2012} & (Chou, 2012) & $\begin{array}{l}\text { A Comparison Study of } \\
\text { Impact Factor in Web of } \\
\text { Science and Scopus } \\
\text { Databases for Engineering } \\
\text { Education and Educational } \\
\text { Technology Journals. }\end{array}$ & $\begin{array}{l}\text { International } \\
\text { Applied } \\
\text { Mechanics }\end{array}$ & $\begin{array}{l}\text { Engineering } \\
\text { education } \\
\text { journals, } \\
\text { educational } \\
\text { technology } \\
\text { journals }\end{array}$ & Impact factor & WoS, Scopus & $\begin{array}{l}\text { Impact Factor } \\
\text { WoS dan } \\
\text { Scopus sama }\end{array}$ \\
\hline & $\begin{array}{l}\text { (Abramo, Cicero, \& } \\
\text { D’Angelo, 2012) }\end{array}$ & $\begin{array}{l}\text { A sensitivity analysis of } \\
\text { researchers' productivity } \\
\text { rankings to the time of } \\
\text { citation observation }\end{array}$ & $\begin{array}{l}\text { Journal of } \\
\text { Informetrics }\end{array}$ & General & $\begin{array}{l}\text { Citations } \\
\text { observed, } \\
\text { sensitivity of } \\
\text { productivity } \\
\text { rankings to } \\
\text { length of } \\
\text { citation } \\
\text { window }\end{array}$ & $\begin{array}{l}\text { Italian } \\
\text { universities } \\
\text { active in the } \\
\text { hard sciences }\end{array}$ & \\
\hline \multirow[t]{4}{*}{2013} & (Chadegani et al., 2013) & $\begin{array}{l}\text { A Comparison between Two } \\
\text { Main Academic Literature } \\
\text { Collections : Web of Science } \\
\text { and Scopus Databases }\end{array}$ & $\begin{array}{l}\text { Asian Social } \\
\text { Science }\end{array}$ & General & $\begin{array}{l}\text { Provenance } \\
\text { and coverage } \\
\text {, Citattion } \\
\text { tracking and } \\
\text { analysis, } \\
\text { Forming and } \\
\text { costs, Impact } \\
\text { factors, } \\
\text { Indexing (h- } \\
\text { index) }\end{array}$ & WoS, Scopus & $\begin{array}{l}\text { Scopus } \\
\text { memiliki } \\
\text { jumlah dan } \\
\text { coverage paling } \\
\text { banyak } \\
\text { dibanding WoS } \\
\text { tetapi dengan } \\
\text { Impact Faktor } \\
\text { yang lebih } \\
\text { lemah } \\
\end{array}$ \\
\hline & $\begin{array}{l}\text { (Adriaanse \& Rensleigh, } \\
\text { 2013) }\end{array}$ & $\begin{array}{l}\text { Web of science, scopus and } \\
\text { google scholar a content } \\
\text { comprehensiveness } \\
\text { comparison }\end{array}$ & $\begin{array}{l}\text { Engineering } \\
\text { Applications } \\
\text { of Artificial } \\
\text { Intelligence }\end{array}$ & $\begin{array}{l}\text { Environmental } \\
\text { sciences } \\
\text { journals }\end{array}$ & $\begin{array}{l}\text { Three citation } \\
\text { resources } \\
\text { (citation } \\
\text { Count, } \\
\text { multiple } \\
\text { copies, }\end{array}$ & $\begin{array}{l}\text { WoS, Scopus, } \\
\text { GS }\end{array}$ & $\begin{array}{l}\text { Dari sisi } \\
\text { Citation Count, } \\
\text { WoS }>\text { GS }> \\
\text { Scopus. } \\
\text { keunikan, } \\
\text { WoS=Scopus }> \\
\text { GS }\end{array}$ \\
\hline & $\begin{array}{l}\text { (Ellegaard \& Wallin, } \\
\text { 2013) }\end{array}$ & $\begin{array}{l}\text { Identification of } \\
\text { environmentally relevant } \\
\text { chemicals in bibliographic } \\
\text { databases: A comparative } \\
\text { analysis }\end{array}$ & Sustainability & $\begin{array}{l}\text { Kimia, } \\
\text { environmental } \\
\text { toxicology }\end{array}$ & $\begin{array}{l}\text { number of } \\
\text { indexed } \\
\text { publications }\end{array}$ & $\begin{array}{l}\text { Scifinder, } \\
\text { WoS, Scopus, } \\
\text { GS }\end{array}$ & $\begin{array}{l}\text { Scifinder } \\
>\text { WoS }=\text { Scopus }> \\
\text { GS }\end{array}$ \\
\hline & (Karyatin, 2013) & $\begin{array}{l}\text { Analisis Perbandingan } \\
\text { Database Jurnal Elektronik } \\
\text { Emerald, Proquest Abi / } \\
\text { Inform dan Springerlink } \\
\text { Bidang Manajemen dan } \\
\text { Ekonomi }\end{array}$ & $\begin{array}{l}\text { Univeristas } \\
\text { Sumatera } \\
\text { Utara }\end{array}$ & $\begin{array}{l}\text { Manajemen } \\
\text { dan ekonomi }\end{array}$ & $\begin{array}{l}\text { Konten } \\
\text { analisis }\end{array}$ & $\begin{array}{l}\text { Emerald, } \\
\text { Proquest } \\
\text { ABI,SpringerL } \\
\text { ink }\end{array}$ & $\begin{array}{l}\text { Proquest }>\text { Sprin } \\
\text { gerLink }>\text { Emeral } \\
\mathrm{d}\end{array}$ \\
\hline
\end{tabular}




\begin{tabular}{|c|c|c|c|c|c|c|c|}
\hline \multirow[t]{3}{*}{2014} & $\begin{array}{l}\text { (Franceschini, Maisano, } \\
\text { \& Mastrogiacomo, 2014) }\end{array}$ & $\begin{array}{l}\text { Scientific journal publishers } \\
\text { and omitted citations in } \\
\text { bibliometric databases: Any } \\
\text { relationship? }\end{array}$ & $\begin{array}{l}\text { Journal of } \\
\text { Informetrics }\end{array}$ & $\begin{array}{l}\text { Manufacturing } \\
\text { Engineering }\end{array}$ & $\begin{array}{l}\text { Relationship } \\
\text { between } \\
\text { omitted } \\
\text { citations and } \\
\text { publishers }\end{array}$ & WoS, Scopus & Scopus $>$ WoS \\
\hline & (Li et al., 2014) & $\begin{array}{l}\text { Chinese-language articles are } \\
\text { not biased in citations: } \\
\text { Evidences from Chinese- } \\
\text { English bilingual journals in } \\
\text { Scopus and Web of Science }\end{array}$ & $\begin{array}{l}\text { Journal of } \\
\text { Informetrics }\end{array}$ & $\begin{array}{l}\text { Chinese- } \\
\text { English } \\
\text { journals }\end{array}$ & $\begin{array}{l}\text { Language } \\
\text { bias in } \\
\text { citations, IF }\end{array}$ & WoS, Scopus & Scopus $>$ WoS \\
\hline & $\begin{array}{l}\text { (Cerovšek \& Mikoš, } \\
\text { 2014) }\end{array}$ & $\begin{array}{l}\text { A comparative study of } \\
\text { cross-domain research output } \\
\text { and citations: Research } \\
\text { impact cubes and binary } \\
\text { citation frequencies }\end{array}$ & $\begin{array}{l}\text { Journal of } \\
\text { Informetrics }\end{array}$ & General & $\begin{array}{l}\text { Relationships } \\
\text { among } \\
\text { citations, } \\
\text { most-cited } \\
\text { papers and h- } \\
\text { indices }\end{array}$ & $\begin{array}{l}\text { Researcher in } \\
\text { Slovenia in } \\
\text { WoS, Scopus, } \\
\text { GS }\end{array}$ & \\
\hline \multirow[t]{4}{*}{2015} & (Ebrahim et al., 2015) & $\begin{array}{l}\text { A Comparison between Web } \\
\text { of Science and Scopus } \\
\text { Databases }\end{array}$ & $\begin{array}{l}\text { Asian Social } \\
\text { Science }\end{array}$ & General & $\begin{array}{l}\text { Citations, } \\
\text { provenance, } \\
\text { coverage, } \\
\text { searching, } \\
\text { citation } \\
\text { tracking, } \\
\text { impact factor, } \\
\text { indexing, h- } \\
\text { index }\end{array}$ & WoS, Scopus & $\begin{array}{l}\text { Scopus } \\
\text { memiliki } \\
\text { jumlah dan } \\
\text { coverage are } \\
\text { paling banyak } \\
\text { dibanding WoS } \\
\text { tetapi dengan } \\
\text { Impact Faktor } \\
\text { yang lebih } \\
\text { lemah }\end{array}$ \\
\hline & $\begin{array}{l}\text { (Mingers \& } \\
\text { Leydesdorff, 2015) }\end{array}$ & $\begin{array}{l}\text { A review of theory and } \\
\text { practice in scientometrics }\end{array}$ & $\begin{array}{l}\text { European } \\
\text { Research on } \\
\text { Management } \\
\text { and Business } \\
\text { Economics }\end{array}$ & General & $\begin{array}{l}\text { Citation data, } \\
\text { citation } \\
\text { metrics, } \\
\text { Impact } \\
\text { Factor, H- } \\
\text { Index }\end{array}$ & WoS, Scopus & \\
\hline & (Ştirbu et al., 2015) & $\begin{array}{l}\text { The Utility of Google } \\
\text { Scholar When Searching } \\
\text { Geographical Literature: } \\
\text { Comparison With Three } \\
\text { Commercial Bibliographic } \\
\text { Databases }\end{array}$ & $\begin{array}{l}\text { Journal of } \\
\text { Academic } \\
\text { Librarianship }\end{array}$ & $\begin{array}{l}\text { Geography, } \\
\text { Geoscience }\end{array}$ & $\begin{array}{l}\text { Bibliographic } \\
\text { database } \\
\text { analysis }\end{array}$ & GS & $\begin{array}{l}\text { GS large degree } \\
\text { of overlap than } \\
\text { WoS, Francis, } \\
\text { Georef }\end{array}$ \\
\hline & (Nanang, 2015) & $\begin{array}{l}\text { Rangking Publikasi Ilmiah } \\
\text { Internasional Indonesia } \\
\text { Bagus Subekti }\end{array}$ & $\begin{array}{l}\text { Socio- } \\
\text { Economic } \\
\text { Planning } \\
\text { Sciences }\end{array}$ & & & & \\
\hline \multirow[t]{6}{*}{2016} & (Maryatun, 2016) & $\begin{array}{l}\text { Pemanfaatan Database Ebsco } \\
\text { dan ProQuest sebagai } \\
\text { Rujukan Penyusunan Tesis } \\
\text { dan Disertasi bagi } \\
\text { Mahasiswa Program } \\
\text { Magister Sains dan Doktor } \\
\text { Fakultas Ekonomika dan } \\
\text { Bisnis UGM : Analisis } \\
\text { Sitiran Jurnal Ilmiah } \\
\end{array}$ & $\begin{array}{l}\text { Informing } \\
\text { Science and } \\
\text { Information } \\
\text { Technology }\end{array}$ & $\begin{array}{l}\text { Bisnis, } \\
\text { ekonomi }\end{array}$ & $\begin{array}{l}\text { Frequency } \\
\text { tabulation and } \\
\text { percentage } \\
\text { calculation of } \\
\text { Kerlinger's } \\
\text { formulas }\end{array}$ & $\begin{array}{l}\text { Ebsco, } \\
\text { Proquest }\end{array}$ & $\begin{array}{l}\text { Ebsco }> \\
\text { Proquest }\end{array}$ \\
\hline & (Zheng et al., 2016) & $\begin{array}{l}\text { Review of the application of } \\
\text { social network analysis ( } \\
\text { SNA ) in construction project } \\
\text { management research }\end{array}$ & $\begin{array}{l}\text { International } \\
\text { Journal of } \\
\text { Surgery Open }\end{array}$ & $\begin{array}{l}\text { Manajemen } \\
\text { projek }\end{array}$ & $\begin{array}{l}\text { Citations, } \\
\text { topic } \\
\text { coverage and }\end{array}$ & WoS, Scopus & \\
\hline & $\begin{array}{l}\text { (Olmeda-Gómez \& de } \\
\text { Moya-Anegón, 2016) }\end{array}$ & $\begin{array}{l}\text { Publishing Trends in Library } \\
\text { and Information Sciences } \\
\text { Across European Countries } \\
\text { and Institutions }\end{array}$ & $\begin{array}{l}\text { Journal of } \\
\text { Business and } \\
\text { Finance } \\
\text { Librarianship }\end{array}$ & $\begin{array}{l}\text { Library and } \\
\text { information } \\
\text { science }\end{array}$ & $\begin{array}{l}\text { Normalized } \\
\text { impact, SJR }\end{array}$ & Scopus & $\begin{array}{l}\text { Peningktan } \\
\text { jurnal berbahsa } \\
\text { inggirs di } \\
\text { bidang LIS }\end{array}$ \\
\hline & $\begin{array}{l}\text { (Franceschini, Maisano, } \\
\text { \& Mastrogiacomo, } \\
\text { 2016) }\end{array}$ & $\begin{array}{l}\text { Empirical analysis and } \\
\text { classification of database } \\
\text { errors in Scopus and Web of } \\
\text { Science }\end{array}$ & $\begin{array}{l}\text { Journal of } \\
\text { Informetrics }\end{array}$ & $\begin{array}{l}\text { Engineering- } \\
\text { Manufacturing }\end{array}$ & $\begin{array}{l}\text { Variety of } \\
\text { errors }\end{array}$ & WoS, Scopus & $\begin{array}{l}\text { Scopus more } \\
\text { accurate WoS }\end{array}$ \\
\hline & $\begin{array}{l}\text { (Wang \& Waltman } \\
\text { 2016) }\end{array}$ & $\begin{array}{l}\text { Large-scale analysis of the } \\
\text { accuracy of the journal } \\
\text { classification systems of Web } \\
\text { of Science and Scopus }\end{array}$ & $\begin{array}{l}\text { Journal of } \\
\text { Informetrics }\end{array}$ & $\begin{array}{l}\text { Classification } \\
\text { system }\end{array}$ & $\begin{array}{l}\text { Citation } \\
\text { analysis }\end{array}$ & WoS, Scopus & WoS $>$ Scopus \\
\hline & $\begin{array}{l}\text { (Moed, Bar-Ilan, \& } \\
\text { Halevi 2016) }\end{array}$ & $\begin{array}{l}\text { A new methodology for } \\
\text { comparing Google Scholar } \\
\text { and Scopus }\end{array}$ & $\begin{array}{l}\text { Journal of } \\
\text { Informetrics }\end{array}$ & $\begin{array}{l}\text { Chinese } \\
\text { Studies, } \\
\text { Linguistics/Co } \\
\text { mputer } \\
\text { Science, }\end{array}$ & $\begin{array}{l}\text { Coverage and } \\
\text { citation } \\
\text { impact, } \\
\text { indexing } \\
\text { speed, and }\end{array}$ & GS, Scopus & $\begin{array}{l}\text { GS }<\text { Scopus, } \\
\text { coverage GS }> \\
\text { Scopus }\end{array}$ \\
\hline
\end{tabular}


Tinjauan Pustaka Sistematis Pada Basis Data Pustaka Digital ... I Aris Yaman, dkk

\begin{tabular}{|c|c|c|c|c|c|c|c|}
\hline & & & & $\begin{array}{l}\text { Inorganic } \\
\text { Chemistry, } \\
\text { Libr. \& Inf. } \\
\text { Sci., Political } \\
\text { Sci., Virology }\end{array}$ & $\begin{array}{l}\text { data quality, } \\
\text { including the } \\
\text { effect of } \\
\text { duplicate } \\
\text { citation } \\
\text { counts }\end{array}$ & & \\
\hline & $\begin{array}{l}\text { (Wang \& Waltman } \\
\text { 2016) }\end{array}$ & $\begin{array}{l}\text { A review of the literature on } \\
\text { citation impact indicators }\end{array}$ & $\begin{array}{l}\text { Journal of } \\
\text { Informetrics }\end{array}$ & $\begin{array}{l}\text { Informetrics, } \\
\text { Information } \\
\text { Science, } \\
\text { Information } \\
\text { Science and } \\
\text { Technology, } \\
\text { Research } \\
\text { Policy, } \\
\text { Scientometric } \\
\end{array}$ & $\begin{array}{l}\text { Citation } \\
\text { impact } \\
\text { indicators }\end{array}$ & $\begin{array}{l}\text { WoS, Scopus, } \\
\text { GS }\end{array}$ & $\begin{array}{l}\text { Scopus } \\
\text { memiliki } \\
\text { coverage yng } \\
\text { lebih luas dalam } \\
\text { bidang social } \\
\text { science, } \\
\text { humanities, and } \\
\text { engineering \& } \\
\text { technology, }\end{array}$ \\
\hline & $\begin{array}{l}\text { (Mongeon \& Paul-Hus } \\
\text { 2016) }\end{array}$ & $\begin{array}{l}\text { The journal coverage of Web } \\
\text { of Science and Scopus: a } \\
\text { comparative analysis }\end{array}$ & SINDO & & & WoS, Scopus & \\
\hline 2017 & (Chadegani et al. 2017) & $\begin{array}{l}\text { A Comparison between Two } \\
\text { Main Academic Literature } \\
\text { Collections : Web of Science } \\
\text { and Scopus Databases. }\end{array}$ & $\begin{array}{l}\text { Biological } \\
\text { Conservation }\end{array}$ & General & $\begin{array}{l}\text { Provenance } \\
\text { and coverage } \\
\text {, Citattion } \\
\text { tracking and } \\
\text { analysis, } \\
\text { Forming and } \\
\text { costs, Impact } \\
\text { factors, } \\
\text { Indexing (h- } \\
\text { index) }\end{array}$ & WoS, Scopus & $\begin{array}{l}\text { Scopus } \\
\text { memiliki } \\
\text { jumlah dan } \\
\text { coverage are } \\
\text { paling banyak } \\
\text { dibanding WoS } \\
\text { tetapi dengan } \\
\text { Impact Faktor } \\
\text { yang lebih } \\
\text { lemah }\end{array}$ \\
\hline & (Calver et al. 2017) & $\begin{array}{l}\text { Why discrepancies in } \\
\text { searching the conservation } \\
\text { biology literature matter }\end{array}$ & $\begin{array}{l}\text { Clinica y } \\
\text { Salud }\end{array}$ & $\begin{array}{l}\text { Conservation } \\
\text { biologists }\end{array}$ & $\begin{array}{l}\text { Citation } \\
\text { counts Cited } \\
\text { reference } \\
\text { search }\end{array}$ & $\begin{array}{l}\text { WoS, GS, } \\
\text { Scopus }\end{array}$ & $\begin{array}{l}\text { Most widely } \\
\text { used databases } \\
\text { were GS }(88 \%) \text {, } \\
\text { WoS }(59 \%) \text {, } \\
\text { WoSCC }(58 \%) \\
\text { and Scopus } \\
(27 \%)\end{array}$ \\
\hline & $\begin{array}{l}\text { (Fernández-Guerrero \& } \\
\text { Palacios-Vicario 2017) }\end{array}$ & $\begin{array}{l}\text { El trastorno límite de } \\
\text { personalidad en la } \\
\text { producción científica } \\
\text { publicada en revistas editadas } \\
\text { en España }\end{array}$ & $\begin{array}{l}\text { Decision } \\
\text { Support } \\
\text { Systems }\end{array}$ & Psychology & & & \\
\hline & $\begin{array}{l}\text { (Sánchez, de la Cruz Del } \\
\text { Río Rama, \& García } \\
\text { 2017) }\end{array}$ & $\begin{array}{l}\text { Bibliometric analysis of } \\
\text { publications on wine tourism } \\
\text { in the databases Scopus and } \\
\text { WoS }\end{array}$ & $\begin{array}{l}\text { Food } \\
\text { Chemistry }\end{array}$ & Wine tourism & $\begin{array}{l}\text { Bibliometric } \\
\text { analysis } \\
\text { Overlap }\end{array}$ & Scopus, WoS & $\begin{array}{l}\text { Scopus covers } \\
\text { the area of wine } \\
\text { tourism better }\end{array}$ \\
\hline & (Joshi et al. 2017) & $\begin{array}{l}\text { Comparison Between Scopus } \\
\text { \& Isi Web Of Science }\end{array}$ & $\begin{array}{l}\text { Journal of } \\
\text { Academic } \\
\text { Librarianship }\end{array}$ & $\begin{array}{l}\text { Biomedical } \\
\text { sciences, } \\
\text { natural } \\
\text { sciences, } \\
\text { engineering, } \\
\text { social } \\
\text { sciences, arts } \\
\text { \& humanities. }\end{array}$ & $\begin{array}{l}\text { Content } \\
\text { Analysis }\end{array}$ & Scopus, WoS & $\begin{array}{l}\text { Scopus lebih } \\
\text { unggul } \\
\text { coverage area } \\
\text { dalam hal health } \\
\text { and medical di } \\
\text { banding WoS }\end{array}$ \\
\hline & $\begin{array}{l}\text { (Aleixandre-Benavent et } \\
\text { al. 2017) }\end{array}$ & $\begin{array}{l}\text { Trends in scientific research } \\
\text { on climate change in } \\
\text { agriculture and forestry } \\
\text { subject areas (2005-2014) }\end{array}$ & $\begin{array}{l}\text { Journal of } \\
\text { Cleaner } \\
\text { Production }\end{array}$ & $\begin{array}{l}\text { Climate } \\
\text { change } \\
\text { Agriculture }\end{array}$ & $\begin{array}{l}\text { Research } \\
\text { collaboration } \\
\text { Bibliometrics } \\
\text { Social } \\
\text { network } \\
\text { analyses }\end{array}$ & WoS & $\begin{array}{l}\text { Determine the } \\
\text { indicators of } \\
\text { scientific } \\
\text { productivity, } \\
\text { impact and } \\
\text { collaboration } \\
\text { between } \\
\text { authors, } \\
\text { institutions and } \\
\text { countries }\end{array}$ \\
\hline & $\begin{array}{l}\text { (Halevi, Moed, \& Bar- } \\
\text { Ilan 2017) }\end{array}$ & $\begin{array}{l}\text { Suitability of Google Scholar } \\
\text { as a source of scientific } \\
\text { information and as a source } \\
\text { of data for scientific } \\
\text { evaluation-Review of the } \\
\text { Literature }\end{array}$ & $\begin{array}{l}\text { Journal of } \\
\text { Informetrics }\end{array}$ & General & $\begin{array}{l}\text { Content } \\
\text { analysis }\end{array}$ & $\begin{array}{l}\text { GS, WoS, } \\
\text { Scopus }\end{array}$ & $\begin{array}{l}\text { GS more cever } \\
\text { in area Social } \\
\text { Science, art and } \\
\text { Human, } \\
\text { engineering dan } \\
\text { computer, GS } \\
\text { more strength in } \\
\text { citation } \\
\text { tracking, GS } \\
\text { less of quality }\end{array}$ \\
\hline
\end{tabular}




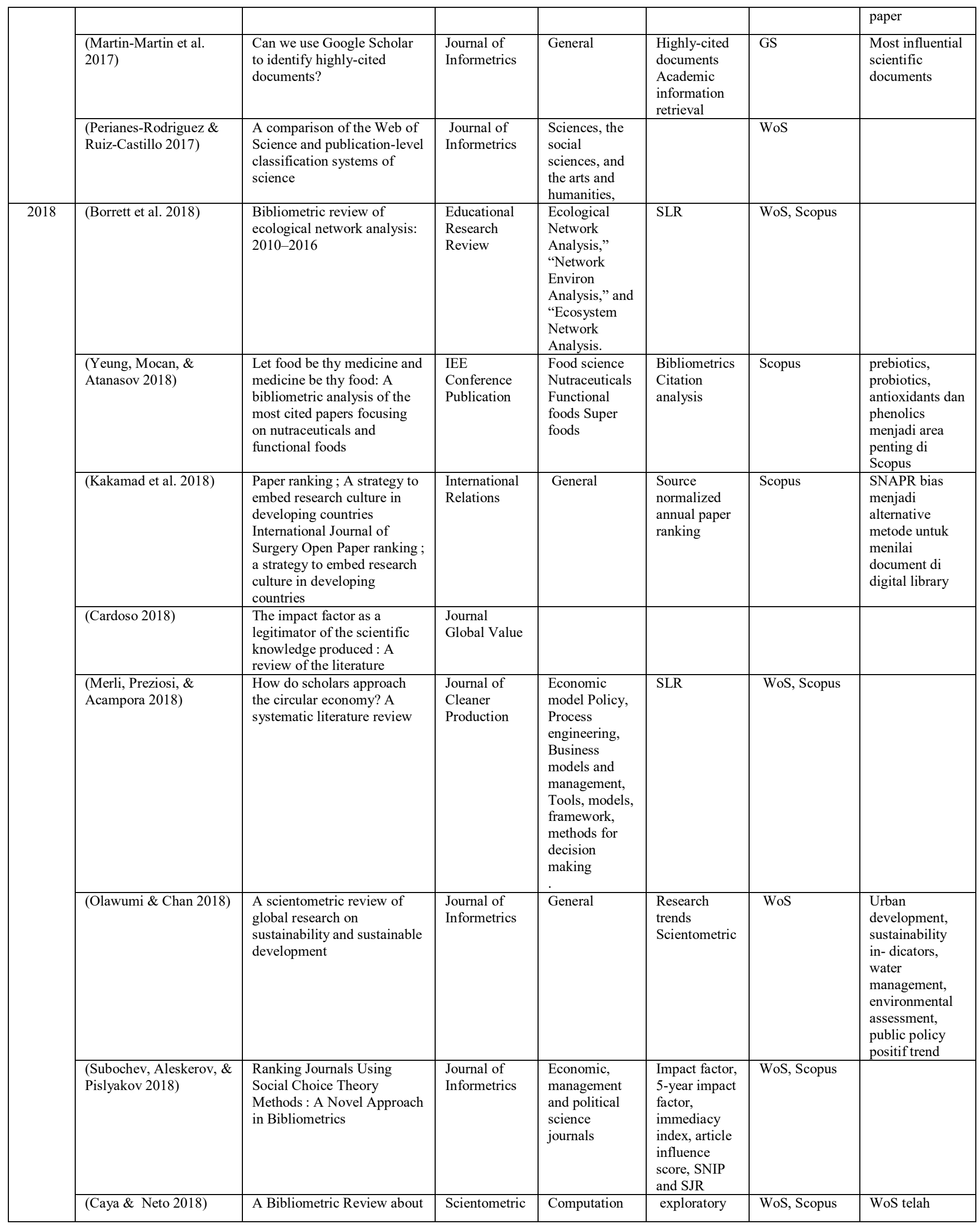


Tinjauan Pustaka Sistematis Pada Basis Data Pustaka Digital ... | Aris Yaman, dkk

\begin{tabular}{|c|c|c|c|c|c|c|}
\hline & Adaptivity & $\mathrm{s}$ & $\begin{array}{l}\text { and } \\
\text { technology }\end{array}$ & $\begin{array}{l}\text { search review } \\
\text { and } \\
\text { bibliometric } \\
\text { indexes. }\end{array}$ & & $\begin{array}{l}\text { mulai } \\
\text { mengembangka } \\
\mathrm{n} \text { indikator } \\
\text { untuk } \\
\text { informetrics } \\
\text { untuk platform } \\
\text { semacam itu, } \\
\text { yang dikenal } \\
\text { sebagaiWebome } \\
\text { trics, seperti: } \\
\text { jumlah } \\
\text { penggunaan }\end{array}$ \\
\hline $\begin{array}{l}\text { (Aldieri, Kotsemir, \& } \\
\text { Vinci 2018) }\end{array}$ & $\begin{array}{l}\text { The impact of research } \\
\text { collaboration on academic } \\
\text { performance: An empirical } \\
\text { analysis for some European } \\
\text { countries }\end{array}$ & SpringerPlus & $\begin{array}{l}\text { Germany, } \\
\text { France, Italy, } \\
\text { the UK and } \\
\text { Russia }\end{array}$ & & Scopus & \\
\hline $\begin{array}{l}\text { (Álvarez-García, Durán- } \\
\text { Sánchez, \& del Río- } \\
\text { Rama 2018) }\end{array}$ & $\begin{array}{l}\text { Scientific coverage in } \\
\text { community-based tourism: } \\
\text { Sustainable tourism and } \\
\text { strategy for social } \\
\text { development }\end{array}$ & $\begin{array}{l}\text { Tourism } \\
\text { Management }\end{array}$ & $\begin{array}{l}\text { Community- } \\
\text { based tourism }\end{array}$ & $\begin{array}{l}\text { Bibliometric } \\
\text { study }\end{array}$ & WoS, Scopus & $\begin{array}{l}\text { Scopus has a } \\
\text { better coverage } \\
\text { in the specific } \\
\text { area of } \\
\text { community } \\
\text { tourism due to } \\
\text { collecting a } \\
\text { greater number } \\
\text { of articles, } \\
\text { journals and } \\
\text { signatures, and } \\
\text { its articles } \\
\text { receiving a } \\
\text { greater number } \\
\text { of citations }\end{array}$ \\
\hline $\begin{array}{l}\text { (Álvarez-García, Durán- } \\
\text { Sánchez, \& del Río- } \\
\text { Rama 2018) }\end{array}$ & $\begin{array}{l}\text { Past themes and future trends } \\
\text { in medical tourism research: } \\
\text { A co-word analysis }\end{array}$ & $\begin{array}{l}\text { Water } \\
\text { (Switzerland) }\end{array}$ & $\begin{array}{l}\text { Medical } \\
\text { tourism Health } \\
\text { tourism }\end{array}$ & $\begin{array}{l}\text { Bibliometric } \\
\text { analysis Co- } \\
\text { word analysis }\end{array}$ & WoS, Scopus & $\begin{array}{l}\text { The results } \\
\text { reveal six } \\
\text { clusters of } \\
\text { themes: a) } \\
\text { issues regarding } \\
\text { ethical } \\
\text { implications, } \\
\text { trust and } \\
\text { accredi- } \\
\text { tation; b) health, } \\
\text { wellness, spa } \\
\text { tourism and } \\
\text { service quality; } \\
\text { c) health-related } \\
\text { issues, medical } \\
\text { treatments and } \\
\text { tourism; d) } \\
\text { "sensitive" } \\
\text { practices in MT; } \\
\text { e) medical } \\
\text { tourism } \\
\text { destinations and } \\
\text { marketing; and } \\
\text { f) globalization, } \\
\text { policies and the } \\
\text { effect on } \\
\text { international } \\
\text { patients. }\end{array}$ \\
\hline $\begin{array}{l}\text { (Durán-Sánchez, } \\
\text { Álvarez-García, \& del } \\
\text { Río-Rama 2018) }\end{array}$ & $\begin{array}{l}\text { Sustainable water resources } \\
\text { management: A bibliometric } \\
\text { overview }\end{array}$ & Water & $\begin{array}{l}\text { Water } \\
\text { Resources } \\
\text { Management }\end{array}$ & $\begin{array}{l}\text { Coverage, } \\
\text { correlation, } \\
\text { overlap, } \\
\text { growth, } \\
\text { citation, } \\
\text { dispersion or } \\
\text { concentration }\end{array}$ & WoS, Scopus & $\begin{array}{l}\text { Scopus } \\
\text { performs better } \\
\text { coverage in the } \\
\text { specific area of } \\
\text { Sustainable } \\
\text { Water Resource } \\
\text { Management by } \\
\text { collecting a } \\
\text { greater number } \\
\text { of articles and } \\
\text { receiving a } \\
\text { greater number }\end{array}$ \\
\hline
\end{tabular}




\begin{tabular}{|c|c|c|c|c|c|c|c|}
\hline & & & & & & & of citations. \\
\hline \multirow[t]{3}{*}{2019} & $\begin{array}{l}\text { (Keenan \& Jankowski } \\
\text { 2019) }\end{array}$ & $\begin{array}{l}\text { Spatial Decision Support } \\
\text { Systems: Three decades on }\end{array}$ & $\begin{array}{l}\text { Decision } \\
\text { Support } \\
\text { Systems } \\
\text { journal }\end{array}$ & General & $\begin{array}{l}\text { Bibliographic } \\
\text { analysis }\end{array}$ & WoS, Scopus & \\
\hline & (Fellnhofer 2019) & $\begin{array}{l}\text { Toward a Taxonomy of } \\
\text { Entrepreneurship Education } \\
\text { Research Literature: A } \\
\text { Bibliometric Mapping and } \\
\text { Visualization }\end{array}$ & $\begin{array}{l}\text { Educational } \\
\text { Research }\end{array}$ & $\begin{array}{l}\text { Entrepreneurs } \\
\text { hip education }\end{array}$ & $\begin{array}{l}\text { Bibliometric } \\
\text { Mapping, } \\
\text { Bibliometric } \\
\text { Visualization, } \\
\text { Systematic } \\
\text { Mapping } \\
\text { Study, } \\
\text { Taxonomy }\end{array}$ & WoS, & $\begin{array}{l}\text { Powerful } \\
\text { intellectual } \\
\text { relationships } \\
\text { among its } \\
\text { contributions } \\
\text { and contributors }\end{array}$ \\
\hline & $\begin{array}{l}\text { (Muhuri, Shukla, \& } \\
\text { Abraham 2019) }\end{array}$ & $\begin{array}{l}\text { Industry 4.0: A bibliometric } \\
\text { analysis and detailed } \\
\text { overview }\end{array}$ & $\begin{array}{l}\text { Engineering } \\
\text { Applications } \\
\text { of Artificial } \\
\text { Intelligence }\end{array}$ & Industry 4.0 & $\begin{array}{l}\text { Bibliometric } \\
\text { study }\end{array}$ & WoS, Scopus & $\begin{array}{l}\text { Difference } \\
\text { coverage area } \\
\text { WoS dan } \\
\text { Scopus. } \\
\text { WoS : } \\
\text { Computer } \\
\text { Science } \\
\text { Telecommunica } \\
\text { tions, Scopus : } \\
\text { Computer } \\
\text { Science } \\
\text { Business, } \\
\text { Management } \\
\text { and Accounting }\end{array}$ \\
\hline
\end{tabular}

Gambar 7 menunjukkan bahwa sebagian besar kajian terkait basis data digital literatur ilmiah difokuskan pada basis data Scopus, WoS, dan Google Scholar dengan peringkat terurut. Hal tersebut menunjukkan bahwa ketiga basis data digital ini masih dianggap paling layak dan tepat sebagai pusat referensi artikel ilmiah.

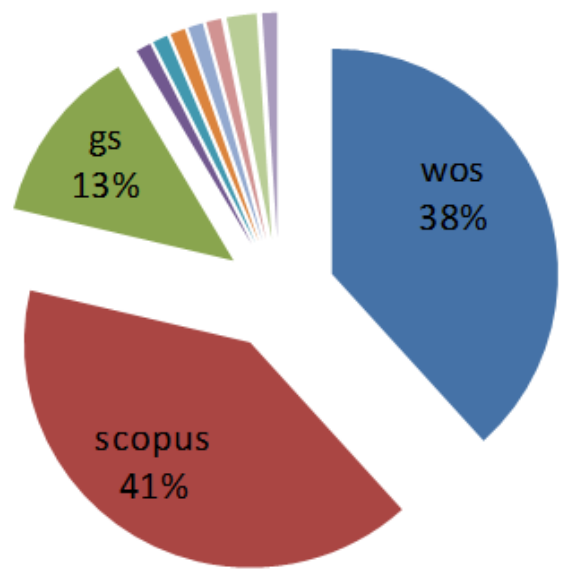

Gambar 7. Distribusi basis data terpilih

Berdasarkan Tabel 5 diketahui bahwa hasil karakterisasi tiap basis data pustaka digital sebagai berikut.

1) Coverage bidang Scopus lebih baik dibanding WoS untuk bidang studi Medical Oncology, jurnal berbahasa Cina - Inggris, Engineering Manufacturing, Classification System, Wine Tourism, Health And Medical (terdaftar Medline), dan Water Resource Management, namun impact factor-nya lebih rendah dibandingkan basis data WoS.

2) Dalam beberapa bidang studi, seperti Engineering Education Journals, Educational Technology Journals, Scopus dan WoS memiliki keunggulan yang sama. 
3) Dalam bidang Bisnis dan Ekonomi, Google Scholar menjadi alternatif pilihan jika dibandingkan dengan WoS dan Scopus, karena memiliki impact factor sama.

4) WoS lebih baik dibandingkan dengan Scopus dan Google Scholar pada bidang studi Environmental Science jika dilihat dari sisi citation count. Pada bidang studi yang sama WoS dan Scopus memiliki tingkat keunikan artikel yang lebih baik jika dibandingkan dengan Google Scholar.

5) Dengan metode Citation Impact Factor diketahui Scopus memiliki coverage yang lebih luas dalam bidang Social Science, Humanities, dan Engineering \& Technology.

6) Scifinder dapat menjadi alternatif pilihan basis data digital untuk bidang studi kimia dan Environmental Toxicology.

7) Basis data Ebsco lebih banyak dan unggul jika dibandingkan dengan basis data Proquest dalam studi Bisnis dan Ekonomi.

8) Basis data Proquest lebih banyak dan unggul jika dibandingkan dengan basis data SpringerLink dan Emerald dalam studi Manajemen dan Ekonomi.

\section{KESIMPULAN}

Journal Informetric, Asian Social Science, Journal of Cleaner Production, dan Journal of Academic Librarianship dapat menjadi rujukan utama tentang basis data digital literatur ilmiah, karena ketiga publikasi tersebut merupakan jurnal dengan SJR terbaik yang dikaji saat ini. Dalam mempelajari keunggulan basis data digital dari sisi konten, kita tidak dapat menggeneralisasi hasil akhirnya karena karakteristik konten database sangat dipengaruhi oleh coverage bidang studi dan cara membandingkannya. Namun, secara umum kita dapat mengkarakterisasi bahwa dalam coverage field keilmuan Medical Oncology, Engineering Education, Educational Technology, Social Science, Humanities, dan Engineering \& Technology basis data pustaka digital Scopus memiliki keunggulan di banding basis data yang lainnya. WoS memiliki karakteristik unggul dalam hal bidang Engineering Education, Educational Technology, dan Environmental Science. Sementara itu, Google Scholar diidentifikasi sebagai basis data pustaka digital yang memiliki kemampuan di bidang studi bisnis dan ekonomi. Google Scholar dapat menjadi alternatif pilihan jika dibandingkan dengan WoS dan Scopus karena memiliki impact factor yang sama. 


\section{DAFTAR PUSTAKA}

Abramo, Giovanni, Tindaro Cicero, \& Ciriaco Andrea D'Angelo. 2012. A Sensitivity Analysis of Researchers' Productivity Rankings to the Time of Citation Observation. Journal of Informetrics 6 (2): 192-201. https://doi.org/10.1016/j.joi.2011.12.003.

Adriaanse, Leslie S., \& Chris Rensleigh. 2013. Web of Science, Scopus and Google Scholar a Content Comprehensiveness Comparison. Electronic Library, 31 (6): 727-44. https://doi.org/10.1108/EL-12-2011-0174.

Aldieri, Luigi, Maxim Kotsemir, \& Concetto Paolo Vinci. 2018. The Impact of Research Collaboration on Academic Performance: An Empirical Analysis for Some European Countries. Socio-Economic Planning Sciences 62: 13-30. https://doi.org/10.1016/j.seps.2017.05.003.

Aleixandre-Benavent, R., J. L. Aleixandre-Tudó, L. Castelló-Cogollos, \& J. L. Aleixandre. 2017. "Trends in Scientific Research on Climate Change in Agriculture and Forestry Subject Areas (2005-2014). Journal of Cleaner Production 147: 406-18. https://doi.org/10.1016/j.jclepro.2017.01.112.

Álvarez-García, José, Amador Durán-Sánchez, \& María de la Cruz del Río-Rama. 2018. Scientific Coverage in Community-Based Tourism: Sustainable Tourism and Strategy for Social Development. Sustainability 10 (4). https://doi.org/10.3390/su10041158.

Bornmann, Lutz, Werner Marx, Hermann Schier, Erhard Rahm, Andreas Thor, \& Hans Dieter Daniel. 2009. Convergent Validity of Bibliometric Google Scholar Data in the Field of Chemistry-Citation Counts for Papers That Were Accepted by Angewandte Chemie International Edition or Rejected but Published Elsewhere, Using Google Scholar, Science Citation Index, S. Journal of Informetrics 3 (1): 27-35. https://doi.org/10.1016/j.joi.2008.11.001.

Borrett, Stuart R., Laura Sheble, James Moody, \& Evan C. Anway. 2018. Bibliometric Review of Ecological Network Analysis: 2010-2016. Ecological Modelling 382 (March): 63-82. https://doi.org/10.1016/j.ecolmodel.2018.04.020.

Boyle, France, \& Damien Sherman. 2006. The Product and Its Development. The Serials Librarian 1095 (May 2014): 37-41. https://doi.org/10.1300/J123v49n03.

Calver, Michael C., Barry Goldman, Patricia A. Hutchings, \& Richard T. Kingsford. 2017. Why Discrepancies in Searching the Conservation Biology Literature Matter. Biological Conservation, 213 (April): 19-26. https://doi.org/10.1016/j.biocon.2017.06.028.

Cardoso, Gustavo. 2018. The Impact Factor as a Legitimator of the Scientific Knowledge Produced: A Review of the Literature. International Relations 9 (2): 32-44. https://doi.org/10.26619/1647-7251.9.2.3.

Casagrandi, R., \& G. Guariso. 2009. Impact of ICT in Environmental Sciences: A Citation Analysis 1990-2007. Environmental Modelling and Software 24 (7): 865-71. https://doi.org/10.1016/j.envsoft.2008.11.013.

Caya, Rosalia, \& João José Neto. 2018. A Bibliometric Review about Adaptivity. Procedia Computer Science 130: 1114-19. https://doi.org/10.1016/j.procs.2018.04.163.

Cerovšek, Tomo, \& Matjaž Mikoš. 2014. A Comparative Study of Cross-Domain Research Output and Citations: Research Impact Cubes and Binary Citation Frequencies. Journal of Informetrics 8 (1): 147-61. https://doi.org/10.1016/j.joi.2013.11.004. 
Chadegani, Arezoo Aghaei, Hadi Salehi, Melor Yunus, Hadi Farhadi, Masood Fooladi, \& Maryam Farhadi. 2017. A Comparison between Two Main Academic Literature Collections: Web of Science and Scopus Databases. Asian Social Science 9 (5): 18-26. https://doi.org/10.5539/ass.v9n5p18.

Chadegani, Arezoo Aghaei, Hadi Salehi, Melor Md Yunus, Hadi Farhadi, Masood Fooladi, Maryam Farhadi, \& Nader Ale Ebrahim. 2013. A Comparison between Two Main Academic Literature Collections: Web of Science and Scopus Databases. Asian Social Science 9 (5). https://doi.org/10.5539/ass.v9n5p18.

Chou, Pn. 2012. A Comparison Study of Impact Factor in Web of Science and Scopus Databases for Engineering Education and Educational Technology Journals. Informing Science and Information Technology 9. https://doi.org/10.7763/IJIET.2012.V2.209.

Durán-Sánchez, Amador, José Álvarez-García, and María de la Cruz del Río-Rama. 2018. Sustainable Water Resources Management: A Bibliometric Overview. Water (Switzerland) 10 (9): 1-19. https://doi.org/10.3390/w10091191.

Ebrahim, Nader Ale, N Ale Ebrahim, Hadi Salehi, Arezoo Aghaei, \& Hadi Farhadi. 2015. A Comparison between Web of Science and Scopus Databases. Asian Social Science, no. May. https://doi.org/10.5539/ass.v9n5p18.

Ellegaard, Ole, \& Johan A. Wallin. 2013. Identification of Environmentally Relevant Chemicals in Bibliographic Databases: A Comparative Analysis. SpringerPlus 2 (1): 1-14. https://doi.org/10.1186/2193-1801-2-255.

Fellnhofer, Katharina. 2019. Toward a Taxonomy of Entrepreneurship Education Research Literature: A Bibliometric Mapping and Visualization. Educational Research Review. https://doi.org/10.1016/j.edurev.2018.10.002.

Fernández-Guerrero, María José, \& Beatriz Palacios-Vicario. 2017. El Trastorno Límite de Personalidad En La Producción Científica Publicada En Revistas Editadas En España. Clinica y Salud 28 (3): 147-53. https://doi.org/10.1016/j.clysa.2017.05.002.

Franceschini, Fiorenzo, Domenico Maisano, \& Luca Mastrogiacomo. 2014. Scientific Journal Publishers and Omitted Citations in Bibliometric Databases: Any Relationship?. Journal of Informetrics 8 (3): 751-65. https://doi.org/10.1016/j.joi.2014.07.003.

Franceschini, Fiorenzo, Domenico Maisano, \& Luca Mastrogiacomo. 2016. Empirical Analysis and Classification of Database Errors in Scopus and Web of Science. Journal of Informetrics 10 (4): 933-53. https://doi.org/10.1016/j.joi.2016.07.003.

Gavel, Ylva, \& Lars Iselid. 2008. Web of Science and Scopus: A Journal Title Overlap Study. Online Information Review 32 (1): 8-21. https://doi.org/10.1108/14684520810865958.

Guz, AN, \& J. J.Rushchitsky. 2009. Scopus: A System for The Evaluation of Scientific Journals. International Applied Mechanics, 45 (4): 351-62.

Ha, Ilkyu, Hohwan Park, \& Chonggun Kim. 2014. Analysis of Twitter Research Trends Based on SLR. International Conference on Advanced Communication Technology, ICACT, 774-78. https://doi.org/10.1109/ICACT.2014.6779067.

Halevi, Gali, Henk Moed, \& Judit Bar-Ilan. 2017. Suitability of Google Scholar as a Source of Scientific Information and as a Source of Data for Scientific Evaluation-Review of the Literature. Journal of Informetrics 11 (3): 823-34. https://doi.org/10.1016/j.joi.2017.06.005. 
Hwang, San-yih, Chih-ping Wei, \& Yi-fan Liao. 2010. Coauthorship Networks and Academic Literature Recommendation. IEE Conference Publication 9 (2004-10711): 323-34. https://doi.org/10.1016/j.elerap.2010.01.001.

Joshi, Aditi, Gurukul Mahila, Mahavidhyalaya Kalibadi, \& Road Raipur. 2017. Comparison Between Scopus \& ISI Web of Science. Journal Global Value, July.

Kakamad, Fahmi H, Q S Rawezh, H M Shvan, A H Dahat, A H Hunar, \& Snur Othman. 2018. Paper Ranking; A Strategy to Embed Research Culture in Developing Countries International Journal of Surgery Open Paper Ranking, a Strategy to Embed Research Culture in Developing Countries. International Journal of Surgery Open 15 (November), 56-59. https://doi.org/10.1016/j.ijso.2018.11.004.

Karyatin, Arianiansyah. 2013. Analisis Perbandingan Database Jurnal Elektronik Emerald, Proquest Abi/Inform dan Springerlink Bidang Manajemen dan Ekonomi. Medan: Univeristas Sumatera Utara.

Keenan, Peter Bernard, \& Piotr Jankowski. 2019. Spatial Decision Support Systems: Three Decades On. Decision Support Systems, 116 (October 2018), 64-76. https://doi.org/10.1016/j.dss.2018.10.010.

Kitchenham, B., \& S. Charters. 2007. Issue: EBSE 2007-001. Technical Report, Vol.2.

Levine-Clark, Michael, \& Esther L. Gil. 2009. A Comparative Citation Analysis of Web of Science, Scopus, and Google Scholar. Journal of Business and Finance Librarianship, 14 (1), 32-46. https://doi.org/10.1080/08963560802176348.

Li, Jiang, Lili Qiao, Wenyuze Li, \& Yidan Jin. 2014. Chinese-Language Articles Are Not Biased in Citations: Evidences from Chinese-English Bilingual Journals in Scopus and Web of Science. Journal of Informetrics 8 (4): 912-16. https://doi.org/10.1016/j.joi.2014.09.003.

López-Illescas, Carmen, Félix de Moya-Anegón, \& Henk F. Moed. 2008. Coverage and Citation Impact of Oncological Journals in the Web of Science and Scopus. Journal of Informetrics 2 (4), 304-16. https://doi.org/10.1016/j.joi.2008.08.001.

Martin-Martin, Alberto, Enrique Orduna-Malea, Anne Wil Harzing, \& Emilio Delgado LópezCózar. 2017. Can We Use Google Scholar to Identify Highly-Cited Documents?. Journal of Informetrics 11 (1), 152-63. https://doi.org/10.1016/j.joi.2016.11.008.

Maryatun. 2016. Pemanfaatan Database EBSCO dan ProQuest Sebagai Rujukan Penyusunan Tesis dan Disertasi Bagi Mahasiswa Program Magister Sains dan Doktor Fakultas Ekonomika dan Bisnis UGM: Analisis Sitiran Jurnal Ilmiah. Ilmu Perpustkaan dan Informasi XII: 123-35.

Meho, Lokman I, \& Kiduk Yang. 2007. Impact of Data Sources on Citation Counts and Rangkings of LIS Faculty: Web of Science Versus Scopus and Google Scholar. Journal of The American Society for Information Science and Technology 58 (13), 2105-25. https://doi.org/10.1002/asi.

Merli, Roberto, Michele Preziosi, \& Alessia Acampora. 2018. How Do Scholars Approach the Circular Economy? A Systematic Literature Review. Journal of Cleaner Production 178, 703-22. https://doi.org/10.1016/j.jclepro.2017.12.112.

Mingers, John, \& Loet Leydesdorff. 2015. A Review of Theory and Practice in Scientometrics. European Journal of Operational Research $246 \quad$ (1), 1-19. 
https://doi.org/10.1016/j.ejor.2015.04.002.

Moed, Henk F., Judit Bar-Ilan, \& Gali Halevi. 2016. A New Methodology for Comparing Google Scholar and Scopus. Journal of Informetrics 10 (2), 533-51. https://doi.org/10.1016/j.joi.2016.04.017.

Mongeon, Philippe, \& Adèle Paul-Hus. 2016. The Journal Coverage of Web of Science and Scopus: A Comparative Analysis. Scientometrics, $106 \quad$ (1): 213-28. https://doi.org/10.1007/s11192-015-1765-5.

Moussa, Salim \& Mourad Touzani. 2010. Ranking Marketing Journals Using the Google ScholarBased Hg-Index. Journal of Informetrics 4 (1), 107-17. https://doi.org/10.1016/j.joi.2009.10.001.

Muhuri, Pranab K, Amit K Shukla, \& Ajith Abraham. 2019. Industry 4.0: A Bibliometric Analysis and Detailed Overview. Engineering Applications of Artificial Intelligence, 78 (December 2018), 218-35. https://doi.org/10.1016/j.engappai.2018.11.007.

Nanang, Oleh. 2015. Rangking Publikasi Ilmiah Internasional Indonesia Bagus Subekti. SINDO, 2015.

Olawumi, Timothy O., \& Daniel W.M. Chan. 2018. A Scientometric Review of Global Research on Sustainability and Sustainable Development. Journal of Cleaner Production, 183: 23150. https://doi.org/10.1016/j.jclepro.2018.02.162.

Olmeda-Gómez, Carlos, \& Félix de Moya-Anegón. 2016. Publishing Trends in Library and Information Sciences Across European Countries and Institutions. Journal of Academic Librarianship 42 (1): 27-37. https://doi.org/10.1016/j.acalib.2015.10.005.

Perianes-Rodriguez, Antonio, \& Javier Ruiz-Castillo. 2017. A Comparison of the Web of Science and Publication-Level Classification Systems of Science. Journal of Informetrics 11 (1): 32 45. https://doi.org/10.1016/j.joi.2016.10.007.

Sánchez, Amador Durán, María de la Cruz Del Río Rama, \& José Álvarez García. 2017. Bibliometric Analysis of Publications on Wine Tourism in the Databases Scopus and WoS. European Research on Management and Business Economics 23 (1), 8-15. https://doi.org/10.1016/j.iedeen.2016.02.001.

Scimago Lab. 2019. Scimago Journal \& Country Rank. 2019. https://www.scimagojr.com/countryrank.php.

Ştirbu, Simona, Paul Thirion, Serge Schmitz, Gentiane Haesbroeck, \& Ninfa Greco. 2015. The Utility of Google Scholar When Searching Geographical Literature: Comparison With Three Commercial Bibliographic Databases. Journal of Academic Librarianship 41 (3), 322-29. https://doi.org/10.1016/j.acalib.2015.02.013.

Subochev, Andrey, Fuad Aleskerov, Vladimir Pislyakov. 2018. Ranking Journals Using Social Choice Theory Methods: A Novel Approach in Bibliometrics. Journal of Informetrics 12: 416-29. https://doi.org/10.1016/j.joi.2018.03.001.

Vakkari, Pertti. 2008. Perceived Influence of the Use of Electronic Information Resources on Scholarly Work and Publication Productivity Pertti. Journal of the American Society for Information Science 59 (4): 602-12. https://doi.org/10.1002/asi.

Wahono, Romi Satria. 2015. A Systematic Literature Review of Software Defect Prediction: Research Trends, Datasets, Methods and Frameworks. Journal of Software Engineering 1 
(1): 1-16. https://doi.org/2356-3974.

Wang, Qi, \& Ludo Waltman. 2016. Large-Scale Analysis of the Accuracy of the Journal Classification Systems of Web of Science and Scopus. Journal of Informetrics 10 (2): 347 64. https://doi.org/10.1016/j.joi.2016.02.003.

Yeung, Andy Wai Kan, Andrei Mocan, and Atanas G. Atanasov. 2018. Let Food Be Thy Medicine and Medicine Be Thy Food: A Bibliometric Analysis of the Most Cited Papers Focusing on Nutraceuticals and Functional Foods. Food Chemistry 269 (June): 455-65. https://doi.org/10.1016/j.foodchem.2018.06.139.

Zheng, Xian, Yun Le, Albert P C Chan, Yi Hu, \& Yongkui Li. 2016. Review of the Application of Social Network Analysis (SNA) in Construction Project Management Research. International Journal of Project Management, 34, 1214-25. https://doi.org/10.1016/j.ijproman.2016.06.005. 